\title{
A EDUCAÇÃO AMBIENTAL NOS LIVROS DIDÁTICOS - (PCN)
}

\section{Felipe Augusto ${ }^{1}$}

Adriane Souza ${ }^{2}$

Resumo: Na atualidade não se observa projetos voltados à educação ambiental, uma vez que há pouca visibilidade no que se refere a esse campo como ferramenta didática utilizada na esfera educacional. 0 conhecimento sobre educação ambiental é essencial para a conservação e manutenção do meio social no qual vivemos. O estudo consiste em analisar como são tratadas as questões ambientais pelos livros didáticos de Geografia e compará-los aos Parâmetros Curriculares Nacionais (PCN) e, também, compartilhar a experiência vivida a partir do desenvolvimento de uma atividade voltada à Educação Ambiental em uma unidade escolar da Rede Pública Estadual do município de São José dos Campos.

Palavras-chave: Educação ambiental; Professores; Alunos; Autonomia; Didática.

\footnotetext{
${ }^{1}$ Geografia/Univap, Brasil. E-mail: flrjp@hotmail.com.

2 Geografia/Univap, Brasil. E-mail: adriane@univap.br.
} 